\title{
Control of Tall Fescue in Kentucky Bluegrass Turf with Selective Herbicides
}

\author{
J.M. Goatley, Jr. ${ }^{1}$, A.J. Powell, Jr. ${ }^{2}$, W.W. Witt ${ }^{3}$, and M. Barrett ${ }^{4}$ \\ Agronomy Department, University of Kentucky, Lexington, KY 40546
}

Additional index words. Poa pratensis, Festuca arundinacea, chlorsulfuron, diclofop, sulfometuron

Abstract. Chlorsulfuron, diclofop, and sulfometuron were evaluated for potential use in selective control of tall fescue (Festuca arundinacea Schreb.) in Kentucky bluegrass (Poa pratensis L.). Polynomial trend analyses indicated highly significant linear and quadratic response curves for percentage of tall fescue reduction for each herbicide. Fall and spring treatments with chlorsulfuron and diclofop provided significant tall fescue control, with slight to moderate initial Kentucky bluegrass phytotoxicity. Fall and spring applications of sulfometuron resulted in excellent tall fescue control, but initial Kentucky bluegrass damage was severe and would be unacceptable for high maintenance turf. Chemical names used: 2-chloro- $N$-[[(4-methoxy-6-methyl-1,3,5-triazin-2-yl)amino]carbonyl]-benzenesulfonamide (chlorsulfuron); 2-[4-(2,4-dichlorophenoxy)phenoxy]proponoate (diclofop); $N$-[[(4,6-dimethylpyrimidin-2-yl)amino]carbonyl]2-methoxycarbonyl-benzenesulfonamide (sulfometuron).

Tall fescue is a serious weed contaminant in Kentucky bluegrass turf. The rapid elongation of tall fescue leaves and its clumpy, upright growth habit disrupts the uniformity and overall aesthetic quality of Kentucky

Received for publication 2 Feb. 1989. Funding provided by Kentucky Agriculture Experiment Station. The cost of publishing this paper was defrayed in part by the payment of page charges. Under postal regulations, this paper therefore must be hereby marked advertisement solely to indicate this fact.

'Assistant Professor, Dept. of Agronomy, Mississippi State Univ., Mississippi State, MS 39762. ${ }^{2}$ Extension Professor, Univ. of Kentucky, Lexington, KY 40546.

${ }^{3}$ Associate Professor.

${ }^{4}$ Associate Professor. bluegrass (Beard, 1973). Selective tall fescue control would eliminate total turf renovation since Kentucky bluegrass rhizomes could encroach into areas vacated by the tall fescue. Until recently, chemicals for selective control of tall fescue in Kentucky bluegrass were unavailable. Greenhouse and field studies indicated foliar applications of chlorsulfuron severely inhibited tall fescue growth at levels $\geq 0.07 \mathrm{~kg}$ a.i./ha, while Kentucky bluegrass tolerated levels up to $0.2 \mathrm{~kg}$ a.i./ ha (LaRocque and Christians, 1985; Maloy and Christians, 1986). Dernoeden (1986) reported foliar applications of diclofop during fall or spring at $2.2,3.4$, or $4.5 \mathrm{~kg}$ a.i./ha provided $90 \%$ tall fescue control with minimal Kentucky bluegrass phytotoxicity. Decreases in tall fescue populations growing in combination with warm-season grasses following foliar applications of sulfometuron have also been documented (Downs and Voth, 1984; Miller and Middlebrooks, 1984). The objectives of this study were to determine the appropriate herbicide concentrations and the timing of single and repeated applications of chlorsulfuron, diclofop, or sulfometuron to minimize Kentucky bluegrass phytotoxicity and still reduce the tall fescue population.

Field experiments were conducted at the Agricultural Experiment Station at Spindletop Farm, Lexington, Ky., (Maury silt loam, Typic Paleudalf; pH 6.5) from Nov. 1984 through June 1985 and at Griffin Gate Golf Course outside Lexington (Maury silt loam, Typic Paleudalf; pH 6.5) from Apr. through June 1985. Kentucky bluegrass ('Kenblue') plots that were uniformly contaminated with tall fescue ('KY 31') were selected at each site. Test areas selected were maintained under moderate management with fertilization once a year in the fall at the level of $108 \mathrm{~kg}$ $\mathrm{N} / \mathrm{ha}$. Mowing heights at Spindletop were maintained at $6.3 \mathrm{~cm}$, while plots were maintained at $14 \mathrm{~cm}$ at Griffin Gate.

Herbicide applications of chlorsulfuron, diclofop, and sulfometuron were delivered to $1.8 \times 3.4-\mathrm{m}$ plots with a portable $\mathrm{CO}_{2}$ sprayer delivering 243 liters of water carrier/ha at a pressure of $21 \mathrm{~g} \cdot \mathrm{cm}^{-2}$. To ensure sufficient leaf wetting, plots were sprayed twice to increase the total volume of spray solution delivered to 486 liters $\cdot \mathrm{ha}^{-1}$. Single applications of the herbicides at the full treatment levels were applied on 29 Nov. 1984 at Spindletop Farm. Single spring applications of the herbicides at the full level were made on $5 \mathrm{Apr}$. 1985 , and split applications in the spring at one-half the full treatment level were made on 5 and 19 Apr. at Griffin Gate.

Initial Kentucky bluegrass injury ratings were made 1 week following plot treatment in both fall and spring experiments. Overall 
Table 1. Initial Kentucky bluegrass color rating, change in percentage tall fescue, and final overall plot color rating following fall or spring applications of herbicides. ${ }^{2}$

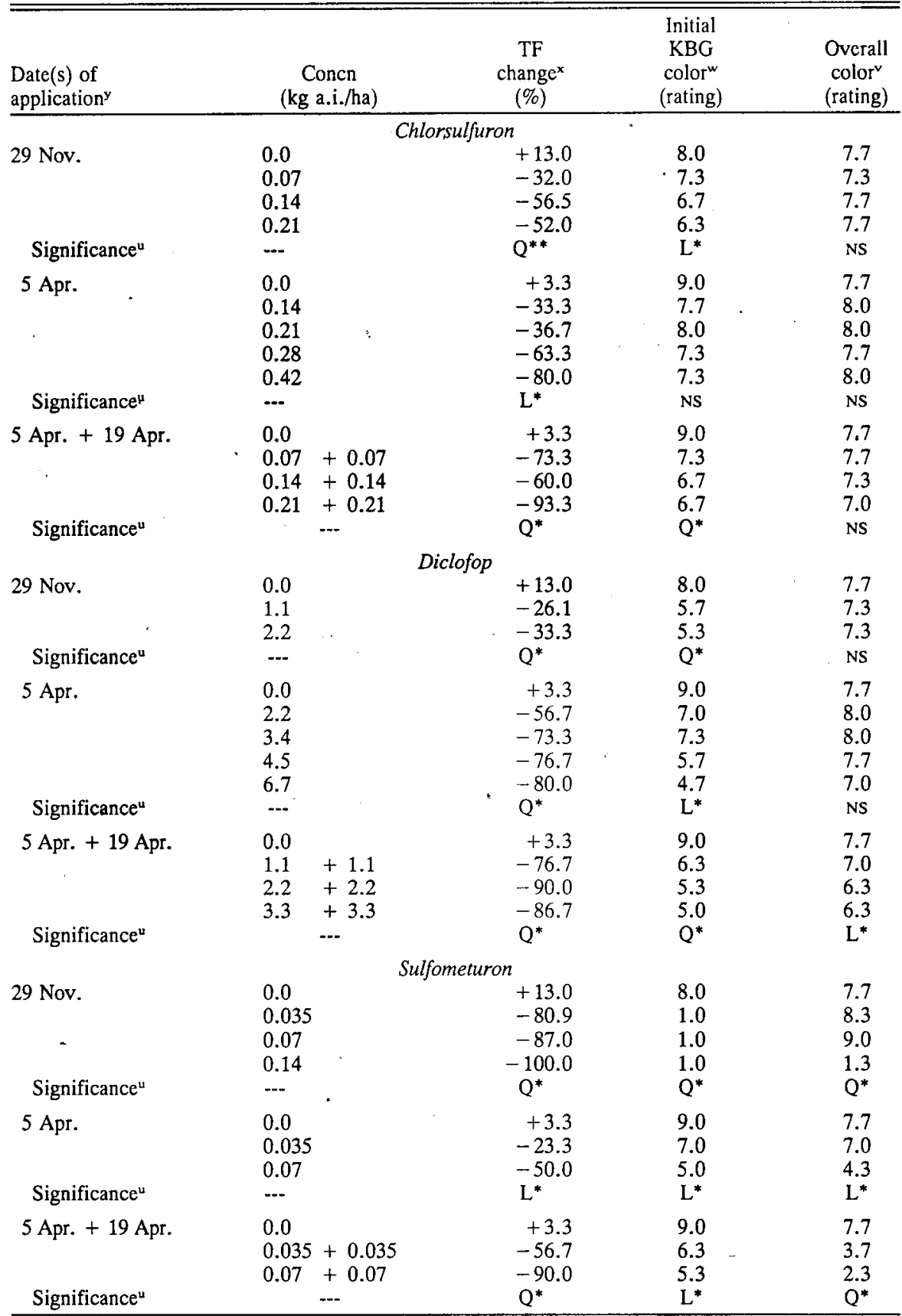

${ }^{2}$ Data are the means of three observations.

y November applications at Spindletop Farm; April applications at Griffin Gate.

xPercentage increase $(+)$ or reduction $(-)$ in tall fescue per plot between the application date and 15 June.

"Initial Kentucky bluegrass color ratings $(9=$ green, $1=$ brown) made 1 weck after final herbicide application.

'Overall plot color ratings ( $9=$ green, $1=$ brown) of Kentucky bluegrass and remaining tall fescue on 15 June.

"Linear (L) and quadratic (Q); nonsignificant (NS) or significant at $P=0.05\left({ }^{*}\right)$ or $0.01\left({ }^{* *}\right)$.

plot color ratings (combining both Kentucky bluegrass and remaining tall fescue color ratings) were evaluated on 15 June 1985 for all treatments. The scale for all color evaluations was $1=$ brown turf to $9=$ green turf. All evaluations on the percentage change in tall fescue per plot were made based on visual estimations of tall fescue contamination of the plots at the time of treatment and at final evaluation on 15 June. level of chlorsulfuron (Table 1). The trend for tall fescue change was quadratic, indicating that the $0.14 \mathrm{~kg}$ a.i./ha level provided a reduction similar to that observed for the $0.21 \mathrm{~kg}$ a.i./ha level. The color ratings of Kentucky bluegrass 1 week after treatment significantly declined as the levels of chlorsulfuron were increased (Table 1). However, while discoloration from chlorsulfuron treatment was noticeable, the degree of discoloration was not severe. Overall evaluations of plot color in June indicated no significant differences between control and chlorsulfuron-treated plots (Table 1).

All levels of chlorsulfuron applied in the single application of 5 Apr. at Griffin Gate caused a reduction in percentage change in tall fescue per plot (Table 1). The tolerance of Kentucky bluegrass to the higher levels of chlorsulfuron was excellent. Also, the higher rates were necessary to achieve substantial tall fescue control in the spring. Only slight discoloration of Kentucky bluegrass was observed for the 0.28 or $0.42 \mathrm{~kg}$ a.i./ha levels of chlorsulfuron 1 week after treatment. No significant differences in overall plot color were observed for any chlorsulfuron treatment on 15 June (Table 1).

Split applications of chlorsulfuron at a 2week interval in the spring resulted in similar reductions in the percentage change in tall fescue per plot as were observed for single applications (Table 1). However, the split applications at $0.07+0.07 \mathrm{~kg}$ a.i./ha provided higher percentage reductions in tall fescue, as compared to the single applications of $0.14 \mathrm{~kg}$ a.i./ha. Initial bluegrass color ratings on $26 \mathrm{Apr}$. tended to be lower for the split chlorsulfuron applications, as compared to the single applications (Table 1). Still, the degree of phytotoxicity was not severe and Kentucky bluegrass had recovered by 15 June.

Diclofop. November applications of diclofop resulted in a quadratic reduction in the percentage change in tall fescue per plot treated at levels ranging from 1.1 to $3.4 \mathrm{~kg}$ a.i./ha (Table 1), but the level of control observed the following June was considerably less than that reported for chlorsulfuron (Table 1). Substantial phytotoxicity to Kentucky bluegrass, as expressed by color, was evident within 1 week after treatment for all levels of diclofop, but recovery of greenness was complete by 15 June (Table 1). Poor tall fescue control and significant Kentucky bluegrass injury from fall applications of diclofop had been reported previously (Dernoeden, 1986)

Trends for percentage change in tall fescue per plot for single and split applications (on a 2-week interval) of diclofop in April were also quadratic (Table 1). Diclofop levels of $3.4 \mathrm{~kg}$ a.i./ha applied alone or $1.1+$ $1.1 \mathrm{~kg}$ a.i./ha provided tall fescue control similar to higher levels of diclofop. Initial Kentucky bluegrass phytotoxicity for single applications of $4.5 \mathrm{~kg}$ a.i./ha or higher resulted in significant color deterioration. However, differences in overall plot color between diclofop-treated plots and untreated controls were not significant, but there was a yellowing trend as the concentration of the 
split applications increased (Table 1). As with chlorsulfuron, Kentucky bluegrass and tall fescue tolerance to higher levels of diclofop treatment appeared to increase in the spring, as compared to overall tolerance of the grasses in the fall. Split applications of diclofop in the spring at levels of $2.2+2.2 \mathrm{~kg}$ a.i./ha or $3.3+3.3 \mathrm{~kg}$ a.i./ha provided excellent tall fescue control but lower color ratings that, however, were acceptable (Table 1).

Sulfometuron. Sulfometuron treatments in fall or spring resulted in the largest reductions in the percentage change of tall fescue per plot of any material examined, but the initial phytotoxicity to Kentucky bluegrass would be unacceptable for high maintenance turf (Table 1). Still, plot color ratings on 15 June following November treatment indicated that Kentucky bluegrass color recovery from sulfometuron treatment at 0.035 or 0.07 $\mathrm{kg}$ a.i./ha was complete and the ratings were actually higher than those for the control plots (Table 1). Recovery of Kentucky bluegrass following sulfometuron treatment at levels of $0.07 \mathrm{~kg}$ a.i./ha or less required $\approx 4$ months, and the greenness became darker for unknown reasons. Kentucky bluegrass did not recover from sulfometuron treatment at 0.14 $\mathrm{kg}$ a.i./ha applied in the fall (Table 1).

Split applications of sulfometuron in April at $0.035+0.035 \mathrm{~kg}$ a.i./ha or $0.07+0.07$ $\mathrm{kg}$ a.i./ha provided better tall fescue control than a single application in April. However, the initial Kentucky bluegrass injury and overall plot discoloration ratings were lower for the split applications (Table 1). Again, tolerance levels of Kentucky bluegrass and tall fescue to sulfometuron treatment appeared to be increased in the spring. The level of percentage reduction in tall fescue per plot following sulfometuron treatment in the-spring at Griffin Gate was generally less than that obtained with either chlorsulfuron or diclofop, and the degree of Kentucky bluegrass phytotoxicity was increased. Sulfometuron use at the lower levels of application in the fall at Spindletop were very effective for tall fescue control, but could only be warranted on turf areas where extended discoloration of Kentucky bluegrass could be tolerated.

These results indicate that chlorsulfuron, diclofop, or sulfometuron can be applied in the fall and spring to reduce tall fescue contamination in Kentucky bluegrass turf. However, the level of tall fescue control and Kentucky bluegrass phytotoxicity varied according to the herbicide used, the herbicide concentration, and the timing of the application. Chlorsulfuron applied in the fall and spring reduced tall fescue contamination without severe initial Kentucky bluegrass discoloration. Diclofop or sulfometuron applications also decreased the percentage change in tall fescue per plot, but initial Kentucky bluegrass phytotoxicity was generally more severe than that observed following chlorsulfuron treatment. For spring applications, higher concentrations of the herbicides were necessary to achieve the degree of tall fescue control observed with lower herbicide concentrations applied in the fall.
Literature Cited

Beard, J.B. 1973. Turfgrass: Science and culture. Prentice-Hall, Englewood Cliffs, N.J.

Dernoeden, P.H. 1986. Selective tall fescue control in Kentucky bluegrass turf with diclofop. Agron. J. 78:660-663.

Downs, J.B. and R.D. Voth. 1984. Roadside weed control with glyphosate and sulfometuron methyl combinations. Proc. Southern Weed Sci. Soc. 37:278.

LaRocque, D.J. and N.E. Christians. 1985. Selective control of tall fescue in Kentucky blue- grass with chlorsulfuron. Agron. J. 77:86-89. Lentner, M. and T. Bishop: 1986. Experimental design and analysis. Valley Book Co., Blacksburg, Va.

Maloy, B.M. and N.E. Christians. 1986. Tolerance of tall fescue and Kentucky bluegrass to chlorsulfuron under field conditions. Weed Sci. 34:431-434.

Miller, J.F. and P.B. Middlebrooks. 1984. Roadside weed control with glyphosate and sulfometuron methyl combinations. Proc. Southern Weed Sci. Soc. 37:278. 